\title{
Kwijtschelding van staatsschuld
}

Citation for published version (APA):

Kimman, E. J. J. M. (1989). Kwijtschelding van staatsschuld. Van Gorcum.

https://doi.org/10.26481/spe.19891006ek

Document status and date:

Published: 06/10/1989

DOI:

10.26481/spe.19891006ek

Document Version:

Publisher's PDF, also known as Version of record

\section{Please check the document version of this publication:}

- A submitted manuscript is the version of the article upon submission and before peer-review. There can be important differences between the submitted version and the official published version of record.

People interested in the research are advised to contact the author for the final version of the publication, or visit the DOI to the publisher's website.

- The final author version and the galley proof are versions of the publication after peer review.

- The final published version features the final layout of the paper including the volume, issue and page numbers.

Link to publication

\footnotetext{
General rights rights.

- You may freely distribute the URL identifying the publication in the public portal. please follow below link for the End User Agreement:

www.umlib.nl/taverne-license

Take down policy

If you believe that this document breaches copyright please contact us at:

repository@maastrichtuniversity.nl

providing details and we will investigate your claim.
}

Copyright and moral rights for the publications made accessible in the public portal are retained by the authors and/or other copyright owners and it is a condition of accessing publications that users recognise and abide by the legal requirements associated with these

- Users may download and print one copy of any publication from the public portal for the purpose of private study or research.

- You may not further distribute the material or use it for any profit-making activity or commercial gain

If the publication is distributed under the terms of Article $25 \mathrm{fa}$ of the Dutch Copyright Act, indicated by the "Taverne" license above, 
Kwijtschelding van stadtsschuld

Serie economische ethiek 

Kwijtschelding van staatsschuld

\section{$R E D E$}

uitgesproken bij de aanvaarding van bet ambt van bijzonder boogleraar in de ethiek van economie en bedriff aan de Rijksuniversiteit Limburg op vrijdag 6 oktober 1989

door

Dr. E.J.J.M. Kimman S.J.

1989 Van Gorcum, Assen/Maastricht. 
01989 Van Gortum 8 Comp B.V.,

Postbus 43, 9400 aA Assen, Nederennd.

Alle rechten voorbehouden. Nicts uir deze uitgave mag worden vervelvoudigd, opgeslagen in een geauromariseerd gegevensbestand, of openbaar gemalk, in enige rorm of op enige wijze, zonder woorafgande schrifrelijke toestemming van de uitgever.

Voorzover het maken wan kopieen uir deze uitgave is toegestaan op grond wan artikel 16B Auteurswet 1912, overeenkomstig het Besluir van 20 juni 1974, St.b. 351 , zoals gewijzigd bij het Besluir wan 23 augustus 1985, St.b. 47 , en artikel 17 Auteurswet 1912, dient men de daarwoor wettelijk verschuldigde vergoedingen te voldoen aan de Stichting Reprorecht (Postbus 882, Ir80 Aw Amstelyeen).

Fotogralie: Sybolt Voeten, Breda.

Vomgeving: Studio Cursief, Amsterdam.

Druk: Leiter Nypels, Maastricht.

Bibliotheek-gegevens:

Kimman, E.J.J.M.

Kwijtschelding van statsschuld/E.J.J.M. Kimman

Assen/Maastricht: Van Gorcum.

(Serie Economische Ethiels: nr. 1)

SISO: 340.8

UDC: 331.1

Trefwoorden: Ethek, economie.

ISBN: 9023225015

Omslag: een van de zes ramen voorstellende allegorieén in de traphal van het stadhuis te Breda. Ontwerp: Joep Nicolas 1926. 
Minheer de Rector Mognifou, dames en beren.

Morele nomen beinwloeden ons gedrag tor op zekere hoogte. In ons keuzegedrag laten we ons leiden door overwegingen van eigen belang, door preferenties, door gevoelens van respect jegens anderen, door tradities en door allerlei andere normen of waarden. Morele normen maken daar deel wan uit inzoverre de moral in ons leven, door opvoeding, en in onze samenleving, door discussie, als een belangrijk goed wordt voorgehouden. Ethiek is een bestudering van de moral en tevens een ondersteuning ervam.

De leerstoel ethiek van economie en bedrijt houd zich bezig met het morele of ethische aspect van alle voortbrenging en beschikbaarstelling van goederen en diensten die door de economische wetenschap onderzoch worden. Wat voorwerp van de economische wetenschap is, de economische realiteit, is ook voorwerp voor reflectie door de economische ethiek. Economische ethiek is geen zelfstandige wetenschap, maar een wetenschappelijk verantwoorde reflectie op wat economisten ook onderzoeken. Ethiek denkt na over de begrippen, de beschrijuingen, de resultaten van economisch onderzoek en over beleidsvoorstellen, die vak deel uitmaken van de conclusies var een economisch betoog.

Het merkwardige bij de conomie is dat we allemal wel wat van economie af weten. Iedereen die mer geld kan ongaan, heeft wel vage noties ontrent het economische. Sommige van die noties zijn simpele vuistregels, andere kunnen morele noties zijn. Veel van war in de politiek, het bedruifslewen of in het huisgezin gedan en besproken wordt, heeft er mee te maken. En, als rechrgeaarde Nederlanders, hebben we ook over van alles en nog wat een mening. Economische ethiek gaat daar niet nog een mening aan roevoegen, mat zal allereerst de vage noties en de vermodens over een rechtvaardige matschappij, over een redelijke inkomensverdeling en over een goed social stelsel onderzoeken. Als Nederlanders mogen we best er en eigen mening op na houden en we hebben het recht die mening aan anderen keabar te maken, mar de ethiek onderzoek of zo'n mening beargumenteed kan worden, of er morele beginselen ann ten grondslag liggen en of die conflicteren met andere beginselen, en of de beleidsadviezen, 
die net zelden $20^{\prime}$ m mening vergezellen, ook mer de beginselen overeenkomstige ethische handelingsaanwijzingen zijn.

\section{Economische ethiek}

Economische ethiek is een nucher onderzoek wan wat zich als advies in de economische wetenschap of als mening in de publieke opine aandient. Economische ethek bevindr zich tussen het economische beldidswoorstel en de publieke opinie in Tussen een objectief rapport en een subjectief publiek gevoelen. Tussen de wetenschappelijke verhandeling en een profetisch spreken.

Is economische ethiek iets nieuws, want het vak wordt nu pas an de economische faculteir roegevoegd, alhoewell deze faculteit al vijf jaar bestart? Is de wijsgerige ethiek, zoals die in een lange traditie van eeuwen in het westen gegroeid is, niet in stat om eenvoudigweg op het deelgebied van de conomie te worden toegepast? Met de benaming 'economische ethiek' wordt een ethische reflectie op het economisch handelen bedoeld. Enerzijds is dat een systemarische reflectie warvan al iets rerug te vinden is bij Thomas van Aquino of de school van Salamanca, anderzijds is het een betrekkelik nieuwe activiteit, voorzover economische ethick gebruik makt en een onderdeel wil zijn van de economische wetenschap. Vanmiddag gaan we kijken, aan de hand van een voorbeeld, hoe economische ethiek te werk gat en hoe zij gesitueerd ksan worden temidden van de reeds bestaande beofening wan de economische werenschap.

\section{De schuldencrisis}

Als voorbeeld nemen we de problemaciek van de sterk gestegen staatsschuden. Zowel in de West-en Oosteuropese landen alsook in een groot aantal landen van de Derde Wereld werkt de overheid met begroringstekorten die gedekt moeten worden door leningen. Weel Wesceuropese landen, zoals Nederland, lenen bimnenlands. Maar veel ontwikkelingslanden lenen in hex butenland. Sinds 1982 is er sprake wan een schuldenerisis: regeringen van sommige ontwikkelingslanden kunnen of willen nauwelijks de rence- en aflossingsverplichtingen op hun externe schulden nakomen. De discussie beweegt zich tussen twee regenovergestelde standpunten: enerzijds beleidsvoorstellen, zoals bijvoombeld het Bakerplan of her Brady-plan, die volgens 
de economische wetenschap verantwoorde oplossingen bieden; anderzijds de gedachte wan schuldkwilschelding gedragen door de publieke opinie, darin gesteund door oproepen van kerkelijke leiders, vooraanstaande polinici en andere invloedrijke personen. Hebben planmen, als bijvoorbeeld het recente Bradyplan, enige morele inhoud: Of is de voor de hand liggende morele oplossing inderdaad slechts kwijtschelding van de staatsschulden? Maar heeft die gedachte dan economische inhoud? Hoe luiden de argumenten hiervoor? Deze vraag wil ik met $U$ gaan bespretsen.

\section{Probleemstelling}

Staatsschuld is de schuld die de stat heet als gevolg van leningen aangegaan door de overheid. In Nederland is, strikt genom men, een staatslening een lening door het rijk of de stat, terwijl een openbare lening, uitgeschreven door een gemeente of provincie, geen stataslening genoemd wordt. In dit betoog wordt schuld van overheidsinstanties waar de staat voor op moet komen, 'sovereign debt' of staatsschuld genoend.

De gewone dekking van overheidsuitgaven wordt gevormd door de inkormsten uit directe en indirecte belastingen en wit de opbrengst van bezirtingen en leningen. Het parlement, in onze democratie, heeft her recht de begroting vast te stellen en daarbij behoort een dekkingsplan. De meeste landen vertonen thans een beeld waarbij jaarlijks de inkomsten achterblijven bij de uitgaven, zodat het tekort gedekt dient te worden uit leningen. Bij inschrijving of door directe bankrelaties wordt zo" $\mathrm{n}$ tekort gedekt. Eenmaal een lening geworden, wordt dit deficit bijgevoegd bij vorige tekorten: de som van deze tekorten is de stantsschuld.

Kan elk tekort zonder meer gedekt worden door een lening? In de vorige eeuw is dar al uitwoerig over gedebatteerd. In ons land spreekt N.G. Pierson wan twee soorten leningen die "principiel" van elkaar verschillen: r) de duurzame lening ter bekostiging van duurzame werken; 2) de tijdelijke lening ter dekking van gewone uitgaven warbij de belasringen in een wolgende periode zodanig moeten worden verhoogd of de uitgaven moeten worden beperkt, dat binnen een zeker aantal jaren de aflossing volgt. "Niet de voorwarden waaronder de 
leningen worden uitgegeven, maken ze dumratam of tijdelik in de gebezigde zin, mar de beginselen, die bij haar uigifte en later worden toegepast." Pierson warschuwt regen het misbruik om ens chronisch deficit te financieren met leningen. Hij wijn erop, dat zo'n afkeurenswardige financieringsaanpak leidr tot een staatsbankroet of tot een onmatige werhoging van de belasingen. Hij wind niet dat er weel gevallen zin warin men duuram lenen kan, ondat "het een volk niet vrij [5tata], de last wan een deel zijner uirgawen op de nakomelingschap over te dragen."

Ruim twee ceuwen geleden werd ingezien dat er een relatie was tussen sluitende overheidshinancien en internationale polirick. In die tijd werd een buitenlandse schuldenlast gezien als een oorlogsrisico, indien namelijk de crediteuren geen rente of aflossing zouden onvangen. In dir werband hoeft her datrom niet te verbazen dat I.Kant zich tegen staatsschuld keerde, omdat hij een vredige, internationale rechrsorde voorstond.2

\section{Externe schulden}

De onwiktelingslanden hebben thans voor rum $\$$ r.300 miljard aan schulden uitstan in het buitenland, woornamelijk bij banken. Regeringen van een aantal van deze landen hebben verklaard dat zij niet meer kunnen voldoen aan hun verplich. tingen. Sinds 1982 zijn voortdurend wisselende groepen banken bezig vormen van herfinanciering te vinden. Supranationale instellingen, zoals het MF en de Wereldbank, zijn bij dit overleg naw betrokken. Er bestan geen faillissementsregels voor staten. De crediteuren, in eerste instantie banken optredend voor de belangen van hun crediteuren, kunnen geen beslag laten leggen op her vermogen van een staat. Wat de crediteuren kunnen is onderthandelen met de desberreffende landen om tot nieuwe betalingsroorwarden en betalingsterminen te komen. Wat de debiteuren-landen kunnen is weigeren meer dan een zeker percentage van hun exporverdiensten an hun credireuren te geven, meegaan met de herfinancievingswoorstellen of hopen op een kwijtschelding van een zo groot mogelijk deel van de schulden.

Toen omstreks $1982-83$ Mexico annkondigde niet langer in stat te zijn zijn rente-verplichtingen na te komen, is men gaan sprekion van een schuldencrisis. Na Mexico volgden meer 
landen: Argentimiê, Brazilie, een par Afrikanse landen. De credireuren voor de Latijnsamerikanse landen waren voornamelik Anerikanse banken. Vandaar dar de Amerikaanse regering zich ermee bemoeide, want zowel het faillerten van een of meer Anerikanse banken alsook een wij plotselinge schuldafschriving door de betreffende banken zou enome gevolgen hebben voor de Amerikaanse schatkist. Het werbaast daarom niet dat plannen die niet zozeer over thw ijtschelding maar over een schuldvergelik spreken, ontstan zijn onder verantwoordeligkheid wan Amerikaanse ministers van financiën: zoals bijvoorbeeld het Baker-plan, genoend naar James Baker, die dit plan in 198 j rijdens een toesprak tot de jaarvergadering van het IMF ontwouwde. Maart dir jar, lanceerde de huidige minister van financien van de V.S., Nicholas Brady, het Brady-plan. Beide plannen willen de landen zoveel armslag geven, dat ze uit hun schuldempositie kunnen groeien, warkdoor ze op een later tijdstip alsnog hum leningen kunnen afbetalen. Middels een sanering wan de economie van die landen, wit te voeren door de regering wan de betreffende landen, en een kapitalsinjectie door een combinatie van westerse banken en de Wereldbank zouden die landen weer tot groei moesen kunnen komen. De redenen voor deze plamen zïn van practische ard: de stabiliteit van het Amerikanse bankwezen, de inkomsten van de Amerikaanse schatkist, of de continuiteit van het internationale bankwezen.

Geheel anders luiden de argumenten van degenen die pleiten voor kwijtschelding wan deze staatsschulden. Die zijn dikwijls van principielle aard: de armoede in deze landen is al schrijnend genoeg wardoor deze landen niet in stat zijn de leningen, waarover valk al hoge rentes betald zijn, terug te betalen. De legitimiteit van zulke leningen wordt in sommige gevallen berwijteld, wanneer het bijoorbeeld gat on de leningen van corrupte, niet meer bestande generalsregimes.

\section{Intemationale schaldverboudingen}

Wat zouden de regels kumen zijn voor internationale schuld. verhoudingen? Is een analogie met de particuliere schuldenar mogelijk? Voor particulieren die hun schuld niet kunnen allossen of hun renteverplichtingen niet kunnen nakomen, hedt al ke samenleving een reeks regels ont wikkeld die de schuldeiser verhalmogelijkheden verschaft maar die de schuldenar bok 
enige bescherming biedt. Indsen een debiteur zin verplichtingen niet nakomt, kunnen de crediteuren beslag laten leggen op het vermogen van de debiteur die immers met dat vermogen heett ingestan voor de schulden. Faillissement is een rechtsinstelling om de aanspraken wan de gezanenlike crediteuren zo goed mogelijk te honoreren waabij de schuldenaar zijn zelfstandigheid als deenemer in de conome rijdelik verliest. Er is een uitrul tussen kapitaal en zeggenschap tor een zekere grens, want een schuldenaar blift recht op een bestaansminimum te hebben.

Schulden van particuliere personen en instellingen verschillen van schulden gemaakt door de publieke sector. We gaan er van uit dat staten thans geen verhaalmogelijkheden bieden zoals wel het geval is bij personen met een vermogen. Oorlogvoening omderwille van niet betalde schulden, zoals I.Kant vreeste, komt ons nu absurd voor. Toch is geweld niet ondenkbaar, want sommige schuldenlanden geven een beeld van toenemende sociale spanningen te zion, wanneer regeringen, afgaande op suggesties van het IMF, wel subsidies afschaffen, mar deze offers niet afruilen tegen meer democratie. Een herstructeringsoplossing, zoals een mational rechtssysteem die biedt in het geval wan surséance van betaling, is nier mogelijk, ondat de staten onderling hiervoor geen internationale rechtsregels hebben ontwikkeld. Waar her recht op een dwingende wije niets regelt, staan wij voor een vacuum. Hoe moer de schuldenproblemariek opgelost worden? Door herstructurering, dus door handhaving van de schuldverhouding, zij her in gewijzigde en soms verminderde vorm, of door kwijtschelding op grond van morele redenen?

\section{Opboww wan bet betoog}

Allereerst gaan we nar de algemene ethiek en we vragen ons af of er algemene ethische regels te vinden zijn die op ons probleem van roepassing zouden kumen ziin. We komen dan tot de ondekking dat dat niet zonder meer mogelijk is. Vervol. gens wagen we of ethick in de zin van een regionale ethiek, die dus uitslutend betrekking heeft op her economisch handelen, die vraag zou kunnen beantwoorden. In een derde poging doen we het voorstel om onze ethische reflectie te laten sporen met de economische wetenschap. Als illustratie gebruiken we dan enige elementen uit de economische denktrant, zoals 
de modelmatige beschriving van de publicke leningen, een cenvoudige manipulatie van een variabele en een uitkomst. Die elementen bevragen wa op hun morele gehalte. We zullen aldus rot criteria komen die een morele uitwag bieden unt het dilemma van de huidige discussie, die de wenselighteid wan kwijtschelding laat prevaleren boven herstruccurering van statasschulden.

Aan het einde van de rede hebben we hopelik dan meer inzichr in de schuldenproblematielk en bovendien in de werkwijze en situering van de economische ethiek binnen de economische wetenschap.

\section{Toepassing van algemene ethische beginselen}

Zou een moreel anvaardbare oplossing van het schuldenprobleem verkregen kunnen worden door simpel het toepassen van een of meer algemene ethische beginselen, zoals bijvoorbeeld rechrvaardigheid of solidariteit?

Alworens dat te doen will ik een algemene opmerking maken over het onderscheid tussen moraal en ethiek, want dat zijn twee begrippen die veel op elkar lijken. Oorspronkelik hadden ze synonieme betekenissen. Thans is het gangbaar geworden om ze verschillend te gebruiken waardoor de feitelijke normen en de reflectie erop onderscheiden kumnen worden. De morele regels waaran mensen zich feitelijk houden, noemen we de moraal, terwijl ethiek de reflectie hierop is. Morele regels zijn dus de regels waarop mensen zich beroepen om hun gedrag te verantwoorden. Niet alle regels kunnen door de ethick gerechtvardigd worden.

Verkeersmoraal betekent de feitelijke manier van deetname aan het werkeer. De leitelijke verkeersmoral van hardrijden, van auto-gebruik, van loodhoudend brandstoffengebruik wil cen beschriuing zijn wan de regels welke mensen zich kennelik stellen of wensen na te lewen, terwij] verkeersethick een begin. sel als veiligheid afweegt tegen een ander beginsel als bijwoorbeeld snel en efficiènt woon-werk-verkeer. Het is een afwegen van ongelijkwardige beginselen, want een verkeer dat absoluut geordend wordt naar het beginsel van veiligheid beraclert een situatie wan stilstand, terwijl de eis van cen snelle verplaat- 
sing wasen wonen en weken dar haths op stat. Over brandstof zou iets dergeliks gezegd kunnen worden vanuit de ongelikwardige af weging tussen eisen van volstrekte milieuneutraliteit en economische eisen van goedkope brandstof.

Met belastingmoraal word bijvoorbeeld angeduid de feitelijke manier wan belastingbetaling c.q. belastingontduking, dat is dus de manier watrop mensen zich wel of niet getwouden achten aan de fiscale rechtsregels. Belastingontuiking mag dan welliche wel door bepalde mensen verdedigd worden met een beroep op iets wat kennelik 'normaal' gevonden wordt. Men stelt dar stipte belastingberaling dan een relatief nadeel mer zich mee brengt ten opzichte van degenen die de belasting. onduiken. Her immorele gedrag van sommigen zer het morele gredrag van anderen op de toch. Zo'n probleem, te vergelijket met cen 'free ride', wordt besproken in de volgende paragraaf als een kwestie van regionale ethiek. Vanuit een algemeen standpunt is belastingethick een reflecrie vanuit algemene beginselen, die vervolgens nomen schrifr, regels ontwikkelt en uitspraken doet over de juiste manier waarop belasting geregeld zou moeten worden en waarop deze regels nageleetd zouden moeten worden.

\section{Drie beginselen}

Thans is de vraga aan de orde of een ethiek die probeert de universele beginselen op te sporen en van daaruit normen te onwikkelen, in staat is een oplossing te vinden voor het probleem wan de exteme staatsschuld van een aantal ontwikkelingslanden. Welke universele beginselen kunnen hierbij van belang zijn? Aan drie beginselen wordt dikwijls gerefereerd: gerechtigheid, solidariteit en autonomie of soevereiniteit.

Nemen we bijvoorbeeld thet beginsel van de gerechtigheid. Hoe zoul op grond wan zo'n beginsel toegelaten kumen worden dat arme landen, war een gedeete van de bevolking al nauwelijks een bestansminimum kent, hun noodzakelike economische groej en, - wat belangrijker is -, hun ecologische reserves prijs geven ter voldoening van overzeese financiële verplichringen? Menig woordvoerder in het debat over de schuldswijtschelding baseer zich op dit beginsel.

Het beginsel van de solidariteit wijkt daar niet zoveel van af, mar legt het accent bij de rijke landen. Solidariteit zou met 
zich mee kunnen brengen dat een rik land, waar iedereen meer dan het bestansminimum kent, hets van de minder noodzakelijke economische rijkdom prijs geef ter wille van arme landen. Toegepast op het probleem van de schulden zou dat kunnen betekenen dat rijke landen niet langer een deel of alles van de uistaande schulden van die arme landen opeisen.

Het derde beginsel is her beginsel van de soevereiniteit. In de decennia na de Tweede Wereldoorlog heeft dit beginsel geleid tot het zogenaamde zelfbeschikkingsrecht van een volk: vele landen, die toen in een koloniale verhouding sronden ror Europese landen overzee, oefenden dat recht wit en werden onafhankelijk in staatkundig opzicht. In de internationale rechtsorde zijn alle staten gelijk. Als stata participeren zij aan international handelsoverleg. Als staat wordt er kapitaal geleend.

De internarionale rechtsorde wordt wel beinvloed door beginselen als gerechrigheid en solidariteit, maar is gegrondvest op de beginselen van soevereiniteit, van onafhankelijkheid en van non-interferentie.

Los gezien wan incidentele reddingsacties bij calamiteiten, zoals natuurampen, worden economische situaties niet als calamieiten maar als min of meer zelf gestuurde, gemaakte siruaries gezien. Eigenlijk heerst de opwatting, dat een slechte economische toestand van een land min of meer zelf in de hand is gewerks: door onverstandig bestuur, door foutieve economische beslissingen of door corruprie van een formeel goede staatsinrichting. In de jaren zestig, toen op grond van het autonomie-beginsel grote delen van Azië en Afrika net gedekoloniseerd waren en toen ontwikkelingshulp, op grond van het beginsel van solidarineit, op gang $k$ wam, was een regering van een onrwikkelingsland domweg en regering. G. Myrdal is toen gaan spreken van de "soft state", waarmee aangegeven word dat staten wel alle gelikwardig maar niet alle gelijk zijn." Thans is het besef vrij algemeen geworden, dat ontwik. kelingstulp veronderstelt dat een hand een goed functionerend bestuur dient te hebben om een economisch beleid uit te voe. ren en aldus cot onwikkeling te komen. ${ }^{*}$

\section{Rije landen, ame staten}

Op grond van welke van deze beginselen zow kwijtschelding 
gerechtwardigd twnnen worden? Louter op grond wan gerechtigheid of op grond van solidariceit lijkt kwijtschelding zonder meer atan te bevelem. Dar is onlangs, wan diverse zujden, gebeurd. Hier is op zich niets tegen in te brengen. Maar waarom een actie wit ten motief wan gerechrigheid ondernemen, als er, gexien de problematiek van de 'soft state', onvoldoende anwijzingen bestan dat de gerechrigheid er inderdad mee gediend zal zin?

Het probleem, dau langs deze algemene argumentering onopgelost blift, is dat dezelfde argumenten ook werden gebruikr om het sluiten van deze leningen, die meestal niet aan de Piersonnorm voldeden, te rechrvaardigen. Een decennium geleden werden aan Latijnsamerikaanse landen, zoals Argentinië, Mexico en Brazilië, leningen verstrekt waarmee voor de armen slechts een consumptieniveau gehandhatd werd en warmee de rijken hun binnenlandse rijkdom konden omzetten in bürenlandse valura. Deze staten zijn in de laatste ro tot 15 jaar niet uit de situatie van de 'soft state" gekomen. De overheid is niet in staat voldoende belasting te heffen. Initiatieven om het probleem van de kapitalwlucht op te lossen worden bij de regeringen van de landen zelf gezoch. Het beginsel van de soevereiniteit begrenst het optreden wan de buitenlandse banken en van de supranationale instellingen.

Voor veel schuldenlanden in Afrika en in het Caraibisch gebied ligt de situatie iets anders, datr meer multilaterale instellingen dan commercietle banken leningen an hen verstrekt hebben. Mar ook dar geldt het algemene beeld dat de economische toestand, ondanks de leningen van de laatste twee decennia, er op achteruit is gegaan. Niet voor niets sprak Myrdal als van een ontwikkelingsdrama. De ontknoping van dit drama is nier goed benaderbaar vanuit algemene beginselen. Overigens kunnen zowel de woorstanders wan $k$ wijtschelding als de voorstanders van een schuldherstructurering zich beroepen op een wan de genoemde algemene beginselen.

Ik ben nier van mening dar een louter verlangen nat gerechtigheid ook dadwerkelijk gerechtigheid bewerkt. Economische ethick als een roegepaste vorm van algemene ethiek helpt de varag ontrent kwijtschelding nier op re lossen. Algemene ethiek wordt te gemakkelik gezien als een systematische discipline die toegepast kan worden op allerlei terreinen. Algemene 
ethek formuleer wel beginselen die vervolgens herleid kunnen worden tot normen die op hun beurt aanwijzingen imhouden woor economisch gedrag, maar algemene ethek mist en instrumentarium dat 'soft agents' als 'moral agents" benadert en dat rekening houdr mer de weerbarstige realiteit van de economie.

Dezelfde bezwaren heb ik jegens varianten op deze algemene benadering, zoals bijvoorbeeld woorstellen wam nieuwe, algemene ordeningen, zoals een nieuwe internarionale arbeidsverdeling, kapitaalsverdeling of grondstoffenverdeling als oplossing van de huidige schuldencrisis. Nergens wordt aangegeven hoe men van de huidige situatie, met een onrechtvaardige, scheve verdeling van werkgelegenheid, kapitaal en grondstoften, komt tot die nieuwe, rechrvaardige situarie. De algemene ethiek laat te veel onbesproken. Zij is in stat een oordeel te geven, mar is niet in staat ann te geven hoe we zo'n nieuwe situatie bereiken. Omdat mensen zich maar ten dele laten leiden door ethisch gerechtvardigde nomen en warden, zal ook de weg naar een meer rechtvardige economische orde bij de beschouwing betrokken moeten worden. Herverdelingswoorstellen zullen die realiteit moeten onderkennen. Anders blijven het utopieen.

In conclusie zie ik drie bezwaren bij een algemene benadering: men wendt de resultaten van de economische wetenschap slechts op een instrumentele wijze aan, want de beginselen en normen zijn afkomstig uit andere disciplines, met name uit de filosofie. De economische kennis dient als illustratie om te laten zien dat het beginsel niet functioneert of de normen niet uitgevoerd worden. Tenslotte wordt een idealbeeld voorgehouden als eindtoestand, zonder dat aangegeven wordr hoe die oplossing tor stand moet worden gebracht. Over de kosten wordt niet gepraat. In ons geval wordt de schuldenlast globaal onder een noemer gebrach, vervolgens veroordect met behulp van de beginselen van rechtvaardigheid of solidariteit, en tenslotte wordt kwijtschelding als een eindtoestand voorgehouden, zonder dat angegeven words. wat het effect is als de schuld afgeschreven wordt.

Hoe vinden wij een denktrant die nier alleen beginselen huldigt, maar ook de consequenties van de uitvoering van deze beginselen in normen en beleid weet door te rekenen? 


\section{Regels voor een sfeer van rationaliteit en zakelijkheid}

De discussie over morele dilemma's, over feitelije moraal en over morele normen bezige en taal die het onderwerp zelf niet alujd recht doet. Morele problemen zinn niet aluijd oplosbaar. Universele beginselen zïn, hoe kan het anders, weinig specifiek. Toch is de prakrijk concreet en an de behoefte aan concrete handelingsaanwijzingen wordt dus niet voldaan. Dit heeft ertoe geleid dat men is gaan spreken wan een moreel relativisme: iemands geweten of iemands culturele context is zo verschillend van het geweten van een ander of de culturele situatie van een ander, dat de normen woor de een uiteraard verschillen wan de normen woor een ander. De culturele context verschilt telkens. Feitelijke normen werschillen wan cul. tuur tot cultur. Gaan achter deze verschillen ook andere principes schuil? Deze fundamentele wrag in de ethiek is het probleem van het relativisme. Zo kan men dan tot een uitsprak komen, dat er zoved moralen zijn als er mensen leven. Mijn weerwoord is, dat dir morele relativisme en het kennelijke morele pluralisme van onze tijd een uitdaging vormt voor de ethiek, omdat ethiek juist op zoek is nar zo algemeen mogelijke beginselen. Algemeen kan dan soms betrekking hebben op her universele van de mensheid, zoals het geval is bij mensenrechten, soms zal het slechts betrekking hebben op een bepaalde culturir, soms zelfis slechts op een levenssfeer. Men spreekt dan van het probleen wan regionalisatie.

Wat is het verschil russen een regionale ethiek en een algemene ethiek? Aan de algemene ethiek worden twee eisen gesteld: dat de regels universaliseerbaar zün en dat ze communiceer. baar zijn. Aan die eerste eis wordt bij een 'regionale ethiek' nee voldaan. Men is geinteresseerd in regels die gelden voor cen bepalde steer of regio wan het menselijk leven, in ons gew val de economie. Deze regels hoeven nier zonder meer buiten de sfeer van 'he economische' te gelden.

Aanwending wan regels wit een regionale ethiek houdt dan in, dac cran uitgegan wordt dat de wereld van de economie en her bedrijl zo apart staan van de rest van het maatschappelijke leven, dar dar een aparte moral geld. Het blijkt dat velen binnen de coonomie dat denken? De morele regels binnen de economie zouden dan sleches betekenis binnen die economic 
hoeven te hebben. Voor zo'n regionale ethek zinn zeler argumenten re vinden als we daarenboven bedenken, dar er ook een eigen recht onwikkeld is voor de feer van de economie.

\section{Ordening wat de economier ethiek en recht}

In de ethische reflectie op de manier warop de economie kennelijk geordend wordt, zinn er drie wijzen van ordening te onderscheiden. De opvallende manier varn ondening zijn de, meestal dwingende, regels van overheidswege. Daarnatst is er zelf-ordening middels afspraken, comenanten en codes, die soms verbindend worden verklaard door de overheid, soms als verbindend worden beschouwd door de rechter en dan weer met eigen tuchtmatregelen beschermo zijn. Tenslotte is er een minder opvallende, vrijwillige ordening aan de hand van morele regels. Rechtsregels, afspraken en morele regels tezamen ordenen de economie. Recht is niet identiek aan moral. Recht is meer dan een afsprak tussen gelijken, want recht is de ordening van hogerhand. Recht veronderstelt een moraal. Een zeker aantal morele wenselitkheden is niettemin beschermd met rechrsegels: bijwoorbeeld een faillissementswet bescherm de zwakke partij. Dat kan aanvankelijk de crediteur, maar vervolgens de debiteur zijn. Een antal wenselijkheden is beschermd of zou best wel eens beschermd kunnen worden door afspraken, denken wij bijworbeeld an milieu-atspraken binnen bedrijstakken, de zogenaande convenanten. Ook een afspraak veronderstelt moraal maar is niet identiek aan moraal. Vrijwilligheid is een voorwarde voor ethisch handelen: het zijn ongeschreven regels, het zijn normen en warden waardoor mensen zich in hum handelingen kennelijk willen laten sturen.

Binnen de rationele en zakelijke sfeer van de economie zijn deze drie wijzen van ordening anwezig: er zijn werten van overheidswege, er zijn zelfgemakke codes en alspraken, en er zijn ongeschreven morele regels. Binnen die sfeer van ordening wan het economisch leven vinden financiële tramsacties, waraonder leningen aan ontwikkelingslanden, plats. In deze sfeer van rationaliteit, waar westerse landen een rationeleve omgang in het domein van de economie kennen dan niet-westerse ontwikkelingslanden, is een geldlening een rationele transactic. Maar het is een transactie warbii an de ene zijde de morele agenten gewend zijn aan een strikt rationed patroon, terwil 
wan de andere zijde de morele agenten in een cultur leven, war vermoedelijk de sfeer van 'het economische' minder is losgemakt van de rest van de maatschappij.

\section{Drie normen}

Hoe kan een contract tussen ongelijk wardige partners een goede basis voor een kredietrelarie zijn? In het algemeen kan woor contracten opgemerkt worden, dat er drie normen werken die tot doel hebben bestaande onevernichtigheden en risjco's te beperken. Ten eerste is er de eis van autonomie, zoals ook in de algemene benadering. Fen particulier of een particuliere bank, optredende namens andere particulieren, met een autonome status heef geen verplichring om een contract aan te gaan met de andere autonome partii, een soevereine staat. Noch de overheid of de overheidsinstelling in het ontwikkelingsland noch de bank of het syndicat van banken was verplicht deze relatie aan te gaan. Een regering in nood is wellicht geen geheel vrije agent, waardoor niet zonder meer van een geldig en moreel acceptabel contract gesproken kan worden.

Ten tweede dient er sprake te zin van een redelike voorstelling war het krediet woor dient en hoe het zal worden terug. betald. Zo'n doeloorzakelijke structur van de overeenkomst is, economisch gesproken, meestal gelegen in de aard van de investering, warvoor het krediet dient. Consumptief krediet is veel moeilijker als een redelijke basis voor een lening te zien dan investeringskrediet. Deze tweede norm kan voorkomen dat pure leniging wan nood getinancierd worde mer leningen. Ten derde is er, voor het allocatie-probleem dat elke transactie is, de norm van Paretoefficiency, dat wil zeggen dat geen der partijen, in termen van de eigen preferenties, nadeel ondervindt. Ideaal is een toestand warbij de positic van geen enkele dechemer meer kan worden verbeterd zonder dat tenminste een andere deelnemer er op acherer uitgat.

\section{Free riders}

Het regionalethische probleem zou hierin dan bestaan: is het mogelijk een ordening in het kapitalverkeer tussen westerse financièle instelingen en soevereine ontwikkelingsianden te vinden, die aan deze drie normen voldoet? Bij gebrek aan een internationale overheid die dxingende regels kan geven, zijn we angewezen voor 20 "n ordening op afspraken of codes en op ongeschreven regels wan momal en fatsoen. 
Een van de belangrijke elementen van het Brady-plan is de wens, dat de verschillende banken afzien wan allerlei begunstigings-clasules en erin toestemmen dat zij gelijkelijk behandeld zullen worden, zoals dat ook het geval is bij een surséance-procedure. Ondat rationaliteir een dominant kenmerk bij her domein van de economie is, zullen sommige bankiers ervoor terugdeinzen om een schuldenvergelijk of een schuldkwijtschelding van hun kant door te voeren, ondat $z i j$ vrezen dat andere banken, weliswar lotgenoten als crediteurs an niet-betalende onwikkelingslanden mar concurrenten voor al het overige, nier mee zullen doen en dus een "free ride' hebben. De 'free riders' wensen vermoedelijk te profiteren van een verbeterd economisch klimaat, waardoor het betreffende land op den duur in staat zal zijn de dan nog uitstaande schulden te voldoen. Moreel gedrag, $\mathrm{kwijtschelding,}$ kost wat; amoreel gedrag, afwachten, betekent een "free ride": een mogelijhheid van een hogere opbrengst in de roekomst. Afwezigheid wan een regionale moral blijkt uir dit problem wan de 'free riders' waardoor een antal banken, uit concurrentie-overwegingen en niet uit gebrek an welwillend. heid jegens ontwikkelingslanden, ervoor terugschrikt een herstructurering en gedeeltelijke kwijtschelding te anvaarden. ${ }^{8}$ Er is dus geen bindend supranationaal gezag en geen consensus ten aanzien van een aanvaardbare moraal die alle bankiers tot de stappen van gedeeltelijke kwijtschelding (20-25\%) en verdere herstructurering kan aanzetten.

\section{Imperfecte wereld}

Economische ethiek, in een regionale betekenis, erkent dat we economisch handeten in cen imperfecte wereld. Ze wil gedragsregels opstellen waraan deelnemers zich vrijwillig willen gaan houden. Het onwikke]en wan een gedragscode voor banken die transacries wensen te doen mer ontwikkelingslanden zal een stap in de goede richting kunnen zijn. Zo'n code zou dan qua structuis kunnen lijken op de Sullivan Code woor bedrijven in Zuid-Afrika, vergezeld van een onathankelijke controle, zonder andere sanctie dan een jarlijkse rapportage door de controle-commissie of toetsende instantie. Ik denk, dat zo'n code zonder meer een goede zaak zou zijh, maar dat de schuldenproblematiek van de ontwikkelingslanden zo urgent is, dar de nodige mentaliteitswerandering en het vertrouwen krigen in $20^{\circ} \mathrm{n}$ code een kwestie van langere adem is dan de urgentie thans toelart. 
Bunen het verzelfstandigde, rationele deelgebied van onze samenleving is een toepassing van een algemeen moreel beginsel even lastig als het werken met een regionale ethiek. Voor zo'n regionale whick zijn codes belangrik. Andere mogelikheden wan ordening zijn nog moeiliker. Gedragscodes ontwikkelen die zow el gedragslinen geven voor westerse bankiers als voor regeringswertegenwoordigers van soevereine staten? Ontwikkelingssamenwerking behelst relaties die intergouwernementeel zijn of tussen een niet-gouvernementele organisarie en een overheid van en ontwikkelingsland. De ethische reflectie over de organisarie van de ontwikkelingsamenwerking is, bij min weten, ner zo belangrijk als de ethiek van zaken doen in ontwikkellingslanden. Codificering van zulke gedragsnormen behoeft ex enhische reflectie die meer doet dan al her gegroeide in betere banen te leiden. Ik kan er vandaag niet verder op in gaan, maar ik hoop in de toekomst binnen het onderzoek aan de faculteit met anderen theraan systematisch te kunnen gaan werken.

De scheve moraal die ontstan is, doordat aan de ene zijde rarionee. werkende banken en an de andere zijde anders ingestelde vertegenwoordigers van regeringen wan debiteurenlanden zich bevinden, is mede een mogelijke oorzaak van de schuldencrisis. Her economische resultat is de uitkomst van niet parallel werkende rationalitteiten. Dit, alsmede de urgentie van het probleem, brengt ons tot de conclusie dat een basis nu ontreekt om zo maar een regionale ethiek te bedrijven. We moeten dus uitzien naat een ander antwoord op onze vraag over een morele aanpak van het probleem van staatsschuld.

We hebben een situatie bereikt waarin sommige contracten echt niet verder uitgevoerd kunnen worden. Voorzier de gewone benadering in een mogelijkheid om de alspraken open te breken? Tot op heden is het karakteristieke van een staatsschuld erin geleger dat deze schuld, ingeval or betalingsmoeilikkheden zijn, geherfinaneierd in plats van geannuleerd wordr door de desbetreffende stat. Repudiatic van schulder is zeldzaam. Het kwam voor ua de Eerste Wereldoorlog in Rusland en Oost Europa. Het probleem warwoor wij thans geplatst worden, dar is de kern wan het Brady-plan, is een gedeeltelijke kwijtschelding, en gedceltelijke herstructurering en een toename van de rol van supranarionale instellingen, als bijvoorbeeld het IMF. Wat zegt de erhielk van het probleen renegotiatie? 


\section{Herstructurering als probleem van economische ethiek}

Het probleem van de schulden is niet hun existentie noch bun omvang maar hun vom. Een staarsschuld wijkt af van een relatie tussen bankier en schuldenaar in de parriculiere sector, omdat er geen regels voorhanden zinn de relarie andere inhoud te geven, indien een van beide partien economisch gesproken dartoe gedwongen wordt. Het probleem van renegotiatie is wel acceprabel in een schuldverhouding binnen de particuliere sector, maar is onbesproken voorzover het staatsschuld betreft. Zijn er morele argumenten te vinden om een staatsschuld niet langer als een gefixeerde lening te zien mar als een financieringsstructuur die van tijd tot rijd rijp is voor renegotiatie? Thans is dit het geval bij een aantal landen. Wat zijn mogelijke normen die voor renegotiatie gebrukt kunnen worden?"

Als algemene en regionale thick niet helpen, dan moeten we ons economisch handelen laten normeren nier alleen door wat we willen maar ook door wat eruit komt. Tussen de uitersten van een unversele Wertrationalität en een regionale $Z$ weckrationalitär ligt het gebied door Max Weber ooit angeduid met Verantwortungsethik, war nu eens de doeleinden dan weer de middelen ons handelen begrenzen en sturen. ${ }^{10}$

We hebben boven gezien dat een globale benadering van het schuldenvraagstuk met een oplossing gebaseerd op universele principes vast loopt op het probleem van de 'soft state'. Het IMF en de banken staan een menu-oplossing woor: ze zoeken case-by-case een oplossing. Van hun kant wordt tekens gesteld dat algemene oplossingen niet mogelijk zijn. Wat is de morele basis van herstructurering en renegotiatie?

Bij staking van bealingen zijn er wee verschillende mogelikheden: en contractuele of een eenzijdige oplossing. Bij een contractuele oplossing worden anspraken, aan beide zijden, geherformuleerd. Bij een eenzijdige oplossing, hetzij schuldre. pudiatie hetzij schuldkwijtschelding, wordt door de ene partij de aanspraak van de andere partij weggewuifd.

Het voorstel van minister Baker hield en adequate financiering van het ampassingsplogramma in, mits de betreffende regering ermee accoord ging: dat is een contractuele oplossing. 
Wat thans voorgested wordt door Brady is ook een contracuele oplossing, maar er zijn flementen terug te winden die een beroep doen op de wrijwillige medewerking van de betreffende bankiers: bjoworbeeld dar alle banken gelijkelijk behandeld moeten gaan worden."

Wat bepleit wordt door vet anderen, een schuldkwijtschelding, is een eenzijdige oplossing genereus natururlijk, maar ook een beetie paternalistisch. We kumen wel zeggen: wat is nou mooier dan een gift? Toch blikt in de economie soms een gift helemal niet zo weldadig. Dartrom moeten we ons afvragen warin een anpak van onderhandeling, waarbij naast schuldverlichting vooral schuldherstructurering voorgestaan wordt, verschilt van de aanpak van schuldkwijtschedding. De wijze wan handelen verschilt: dialoog tussen parners in plaars van een eenzijdige havdeling wit welk motief dan ook. Het wel. vartseffect verschilt: over schuldkwijtschelding is het effect nog onduidelijk, maar bij schuldherstructuering hoeft van een negatief effect geen sprake te zijn. ${ }^{2}$

\section{Monal en economisch denken}

De economische wetenschap, voorzover niet historisch maar actueel bezig, voltrekt zich ruwweg in drie fasen: men beschrift conomische processen op een modelmatige manier; men manipuleert een variabele in dit model; men verkrijgt een uirkomst die relevantie bezit voor de prakripk. Alle economisch denken is enigszins terug te voeren tor deze drie stappen: iets wan de werkelijkheid vastleggen en beschrijuen, bijvoorbeeld met een definitie, een wetmatige bewering of een model. Vervolgens wordt iets uit dat model of uit die bewe. ring een variabele genoemd warmee, met name in de modelmarige economie, dan een manipulatie of een exercitie gedaan wordt. Tenslotte is er een uitkomst met een soort adviesfuncrie.

Van de beschrijuing gat de econoom voeiend over in de exercitie en darna zonder veel probleem naar het advies. Tussen definitie-vergelijkingen en gedragsvergelijkingen bestaat, ethisch gesproken, een verschil. Doeleinden en middelen zijn in de vergelijkingen wan plats verwisselbaar.

Economische ethick reflecteert op de omkeringen die in elk model to maken zijn. Bij elke vergelijking zijn morele afwegingen te maken. Morele bezwaren of voorkeuren kunnen vervol- 
gens economisch gereconstrueerd worden. Het zou te veel tijd vergen om dit allemaal in dir ewe uur toe te lichten. Het is niet zo, dat de economie pas war mag zeggen, als de filosofie uitgepraat is, maar er dient een normaticve reflectie te zin bij her waststellen van de empirische data, bij her opbouwen wan het model, bij het doen van de uitspraken. Toch wil it nier zover gaan om economie een normarieve werenschap te gaan noemen, maar ethek moet wel de morele aspecren, die in iedere beschrijwing, in ieder model en in iedere practische suggestie besloten liggen, er uit lichten, onderzoeken en evalueren. Economisten vervlechten dikwijls morele noties en economische uitspraken. Een wardenvrije wetenschapsbeoefening is een onhalbaar ideaal voor een economist. Waar ik iets op tegen heb is de verkapte manier warop morele preoccupaties als uitkomsten van een economische verhandeling gepresenteerd worden. Ik zal dat illustreren aan de hand van twee kleine voorbeelden: namelijk de minachting van Keynes voor sparen en de obsessie van Buchanan voor schulden.

De vooronderstellingen bij een schulddiscussie betreffen, in de grond genomen, de vermogenspositic: word door een lening uiteindelijk het vermogen van een economische participant zodanig versterkt, dat op een later tijdstip de lening kan terugbetaald worden vanuit en sterkere positie? Van J.M. Buchanan is bekend, dat hij tegen schuld is, omdat hij berwijfelt of een toekomstige generatie een sterkere posirie zal innemen om de leningen terug te betalen. Hij wantrouwt policici om een sichuldprobleem an te pakken.

Buchanan en anderen hebben zich sterk afgezet tegen een vorm van Keynesiaans denken. In de jaren dertig, ten rijde van een uitzichtloze economische depressie, is men anders over sratsschuld gaan denken onder invloed van de theorieen van J.M.Keynes. Het allesbeheersende doel van het project wan Keynes, in 1936, was een beleidsadvies om de werkloosheid terug re dringen. Keynes had in zekere zin een morele boodschap. Niet als ethicus, maar als moralist. Zijn morele noties zijn ingevlochten in her betoog, zonder dat daar apart op gereflecteerd wordt. Hij wilde economische groei door meer bestedingen, want zijn analyse was dar de economie leed aan onderbesteding. Daartoe moest hij de deugd van het sparen ontraden.".

In de jaren vijfig waren de aanvankelijke ideeen van Keynes 
omgebouwd tot een Keynesiantse begrotings-theorie, war conjuncturele en structurele argumenten gebruikt konden wor den om een begrotingstekort te verdedigen. Het is deze staatsschuldbenadering die aangevallen wordt door Buchanan in 19:8. Hij bestrijdr sindsdien de Keynesiaanse begrotingsopvarring die het probleem wan overtheidstekorten onderschat, en de politieke mentaliteit die daarbij hoort. ${ }^{14}$

Buchanan gebruikt de metafoor van de erfenis als hij het problem van de statsschuld ter sprake brengt. Hij ontwikkek een analogie tussen de staat en een persoon. Als hij een andere analogie zou hebben gebrukt. was hij wellicht in een andere riching gaan denken, maar tor op heden is hij bekend van bijvoorbeeld een aanpak als de Gram-Rudman-wet in de V.S.: een oplossing nit gebaseerd op een hernieuwd moreel besef bij kiezers en politici, eventued re bereiken door opvoeding en publieke opinie, en ook niet gebaseerd op onderhandeling, maar op een wettijke constructie.

Voor beide cconomisten geldr, zowel Keynes als Buchanan, dat ze een beschrijuing en een analyse wan de economische werkelijkheid maken, en vervolgens vanuit hum moreel inzicht aangeven welk element in de analyse een variabele is en welk element een doelstelling. ${ }^{15}$ Maar moraal en economie zijn zo vervlochten, dat een ethische analyse van de morele preoccuparies wan beide schrijvers afzonderljik eerst nodig is.

\section{De staat. en financieringstractutur}

Dat de stat functioneert of niet funcrioneert, zoals geillustreerd wordt met een 'soft state", dat de stat rationeel omgaat met zijn crediteuren, en dat een staat zijn uitgaven weet te dekken uit de lopende belastinginkomsten, en eventueel uit leningen, is het resultaat van een lang, historisch proces. Nederland theeft in de loop der geschiedenis verschillende staatsvormen gekend. De Europese eenwording makt de huidige statswormen van cle twalf lidstaren berrekkelik. Veel staten in de ontwikkelingslanden zijn geen 'rationele staten', zoals die in het westen die juist als constructie opgezet zijn om meeriarige risico's te dragen.

War het om gaat is een zodanige vermogenspositic op te bouwen, dat elke nieuwe regering een handelingsvribeid heeft om die doelstellingen te realiseren, wartoe zij een mandaat van de kiezers gekregen heeft. Een staatsschuld moet ondergeschikt zijn an dat beginsel en an andere beginselen, zoals de welvartsverdeling en de ecologische continuiteit. 
Modelmarig kunnen doeleinden en middelen in de conomische wetenschap van plats verwisseld worden. De idee wan de gegarandeerde staatsschuld als invariabell element kan plats maken voor een instrumentele kijk op statsschuld. Wie dat doet kan ook herstrucrurering van statsschuld in har economische proporties zien. We de staatsschuld ziet als een heilige koe, vervalt in eenzjjdige benaderingen: een Gram-Rudmanwet of een totale $k$ wijischelding. Wie economie ziet zoals economisten de economische realiteir bekilken, weet dat er rijke en arme staten zijn. Maar die weet ook, dat er rijke en arme landen zijn. En dat er rijke landen zijn met arme staten, en omgekeerd. Herstructureren van staatsschuld is werken aan een meerzijdige relatie tussen soevereine staten die voor hun groei nog heel weel financiele steun benodigen, en gespeciali. seerde financiële instellingen die gebaat zijn bij her versterken van de vermogenspositie van die landen. Bij $\mathrm{kw}$ ijtschelding houdt de interesse op. Tot nadeel vooral van de arme landen. En hoe dan de zwalke vermogenspositie van zulke tanden verstertkt zou kunner worden, blijt cen raadsel. Ik vrees dat de ecologische reserves van die landen nog zwaarder aangesproken zullen worden dan nu reeds het geval is. In plats van een verwijdering, is samenwerking nodig. Volledige schuldkwijtschelding houdr het gevaar in van ongeinteresseerdheid: het westen verwacht wellich dan niets meer van Afrika of Latijns Amerika en keert zich misschien nog meer to de geỉndustrialiseerde landen van Azië.

Het dubbele effect van kwijtschelding van staatsschuld is dar verouderde opwattingen als "giften zijn een goede financiële hulp aan de ontwikkelingslanden" en "staatsschulden zijn gefixeerde verplichtingen" blijven bestan. Herstructurering heefr ook cen dubbel effect: de financiële relatie met de ontwikkelingslanden wordt een zakelijke en de financiering van de publieke sector gaat het karakter wan gefixeerdheid verliezen. De problemen van de grote staatsschulden in de ontwikkelingslanden ziin vanuit verschillende invalshoeken en langs verschillende morele methoden analyseerbar. Ik heb vanmiddag gekozen voor een benadering van economische orhick en dio brengt ons tot een verassende conclusie. De paradox van de kwijtschelding is dus dat her goed lijkt maar vermoedelijk op den duur minder voordeling zal zijn. Terwijl herstructureringswoorstellen, zoals het Brady-plan, weliswar enige $k$ wijtschelding mogelijk maken, maar voor het overige de verster 
king wan de vermogenspositie middels rationele deelname an het wereldkapitalverheer beogen. De aanpak van hee Bradyplan en van het IMF is hard. Hij vergt offers van saten met een grote schuldenlast die dat van hur bevolking pas kunnen wragen als er een afrull mer meer democratie en andere staatkundige verbeteringen plaats wind. En hij dwingt de banken tor overleg en tot gedragscodes. Toch is zo'n harde aanak moreel de goede en de verkieslike.

\section{Economische ethiek en economische wetenschap}

Erhiek, net als recht, heeft te maken met ordening. Economische ethiek heef dus te maken mer economische ordening. Spontane orde komt nauwelijks woor. Alle economische schrijvers zijn met dat probleem bezig. Vanaf Adam Smith: cen onzichtbare hand zou dan, weliswaar ongezien, wan buiten af sturen. Voor de liberalen uit de negentiende eeuw was het ordenende beginsel her eigenbelang. Voor de christelijke sociale gedachte was dat het gemeenschappelijk belang. Voor her marxisme was dat een ordenende matschappelike structur. Voor economische athiek geldr ook ordening als een belangrijk vragstuk, maar dan wel vrijwillige ordening, een ordening op grond van een moreel besef, gehandhafd door opvoeding, beschermd door een consensus in de samenleving.

Ower ordening, nier alleen in de maatschappij maar ook in de economie, kan men langs twee verschillende lijnen denken: op de eerste plaats kan de ordening van de maatschappij vanuit een idee van ontwikkeling bekeken worden. De gedachre dat dingen hun tijd moeten hebben, dat processen historisch gezien nooit helemat hertalbar zijn en dat er alrijd weer onverwachte verschillen zijn. Op de tweede plats kan er contractueel, makbatr, manipulerbaar over gedacht worden. Dat is de gedachte dat wij de matschappij structureren en sturen kunnea, mits we mar weten wat we willen en ook samen willen wat we erover denken te weten.

Ethek in een ontwikkelingsperspectief benadrukt opvoeding, communicatie en wellicht waarden. Ethiek in een maakbarheidsperspectief benadrukt procedures, discussie en ook nor- 
men. De sociale handelingstheorie die men heet, is dus wan net zo'n groot belang als de metaforen die men arinendt.

De ordening van onze samenleving heeft een kostenaspect. Aan alles is een schaarste-aspect. Bif lange na zijn er niet vol. doende middelen aanwezig on alle behoeften te bevredigen. Dit inziche is in de economische werenschap al lang gemeengoed. Het wordt tijd, dat het doordringt tot buiten de kringen van de vakgenoren. Elke budget-exercitie is kiezen uit beperkte middelen. Een lening is een rijdelijk gebruik van beperkte middelen van anderen die, en ik herhaal, rijdelik bij die anderen nog niet benut worden. Een lening is dus gekoppeld aan het sparen. Een lening dient ook gekoppeld te zijn aan her terugbetalen, aan het eerbiedigen van het recht wan die anderen on de uitgestelde consumptie niet langer uit te stellen.

Wat is nu de bijdrage van de economisthe ethiek aan de algemene beofening van de economische wetenschap die het economische aspect van onze samenleving onderzoekt? Aan steeds meer handelingen wordt een prijskaartie werbonden. De tak van de economische ethiek zou hierin kumnen bestaan aan te geven, dat handelingen war de economisten een kostenaspect wan hebben bekeken, ook een moreel aspect hebben: dat de keuze uit schaarse middelen die alrernatief anwendbaar zün niet slechts economisch maar ook moreel van aard kan zijn. Economische erhiek houdt zich darmee bezig binnen de economische wetenschap. Het is een hulpwerenschap ner als de wiskunde en de statistiek hulpwetenschappen binnen de economische wetenschapsbeoefening zim.

Aan elke economische handeling zijn offers verbonden en bij elke economische situatie behoort een goederenverdeling. Kwijtschelding wan staatsschuld is een handeling met gevolgen voor die verdeling. Min analyse is, dat de schijnbat moreal goede handeling uiteindelik moreel minder wenselijke gevol. gen heef voor de welvaartsverdeling tussen arme en rijke landen. Maar ook bij herstructurering, hoe moeizam ook, is de economie angewezen op offers van beide zijden. Zolang schuldafschrijwing een fiscal effect heeft, brengt ook het Brady-plan offers voor her westen. Zijn we eigenlijk wel bereid tot een hogere belastingaldrache? Het Brady plan doet een beroep op een morel besef niet alleen wan regeringen van ont. wikkelingslanden, en van bankiers, maar ook van elke be- 
lastingetaler. Het aanpaken van statssehulden hange af wan de offerbereidheid van meer zijden. Met wat meer waardering woor sparen, net geobsederd door schulden en open woor renegotiane wan statsschuld bhift de noodzaak wa Magnanimitas: een vrijmoedigheid om te geven. Mar dar is een ander verhal. 
Dames en Heren, leden van het College van Toezicht van de Leerstoel, leden van her Bestur van de Stichting Wetenschappelijk Onderwijs Limburg, en leden wan her College van Bestuar van deze Universiteit: Uw inspanningen, bereidheid, respectievelijk instemming waren de vereisten om deze leerstoel op te zerten en mij als eerste hoogleraar ervoor te benoemen. Ik dank $\mathrm{U}$ voor dit in mij gestelde vertrouwen.

Dames en Heren, leden wan de academische gemeenschap te Maastricht. U hebt mij sinds kort als collega, medewerker en docent in Uw midden opgenomen. Ik hoop dat het vak ethick in de economische wetenschapsbeofening hier zo gewoon gaat worden als econometrie of informaticat dat Mastrichtse economisten hun meerwarde ondenen aan hun moreel besef en hun vermogen dat uit te drukken in economische, rationele categoriear.

Ik dank U woor Uw andacht. 